\title{
Edward Stachura - geopoeta
}

Elżbieta Konończuk

TEKSTY DRUGIE 2020, NR 5, S. 311-327

DOI: 10.18318/td.2020.5.19 | ORCID: 0000-0002-9544-6595

Wszystko jest poezją, a najmniej poezją jest napisany wiersz. [...] Wiele znaków na ziemi i niebie wskazuje na to, że tak istotnie jest. Wiele znaków zwłaszcza na ziemi. [...] Kiedy się jedzie pociągiem, to jest to o ile ciekawsza poezja.Znam takich, którzy wysiadają na jakiejś stacji albo wprost wyskakują z pociągu [...], żeby wejść w krajobraz, który ich nagle olśnił. Żeby być w nim. Wtopić się weń. Być jedną linijką, jednym wersem w tym wierszu. Taki skok z pociągu [...] i pójście przez pola, na przełaj, na sagę - jest przepięknym wierszem, tyle że nie zapisanym na papierze. Ale ja myślę, że zapisany zostaje w powietrzu, odciśnięty zostaje w powietrzu kształt tego wiersza, i znam znowu takich, którzy umieją przepisywać z powietrza i być może tego wiersza nie przegapią, tylko go przepiszą z powietrza, $\mathrm{i}$ inne wiersze przepiszą z powietrza, z wnętrza powietrza. ${ }^{1}$

1 E. Stachura Wszystko jest poezja. Opowieść-rzeka, red. K. Rutkowski, Czytelnik, Warszawa 1984, s. 6.

\section{Elżbieta}

Konończuk - dr hab., prof. Uniwersytetu w Białymstoku, kieruje Zakładem Teorii i Antropologii Literatury. Interesuje się związkami między teorią literatury, historiografią i geografią humanistyczną. Zastępca redaktora naczelnego „Białostockich Studiów Literaturoznawczych". Ostatnia książka: Wposzukiwaniu dostępu do przeszłości. O powieściach warsztatowych Hanny Malewskiej i Jacka Bocheńskiego (Białystok 2009). 
Powyższy fragment opowieści-rzeki Wszystko jest poezja oddaje postawę Edwarda Stachury, który bycie poetą rozumiał jako doświadczanie „w natchnieniu" rzeczywistości. Teza taka - przewijająca się niczym refren w Całej jaskrawości - bliska jest idei „poetyckiego zamieszkiwania ziemi”, głoszonej przez geopoetów. Swoją opowieść-rzekę poeta kończy słowami „wszystko, co napisałem - przepisałem z przestworzy”2. W słowach tych pobrzmiewa w istocie przekonanie o poetyckiej naturze otaczającego świata. Jeśli według Stachury przepięknym wierszem jest skok z pociągu w krajobraz, który nagle olśnił, i pójście przez pola na przełaj, a poetą jest ten, kto przepisuje wiersz z powietrza, to proponowaną przez niego poetykę trzeba nazwać geopoetyką. Stachura, zaprzyjaźniony z francuskim poetą i teoretykiem literatury Michelem Deguy³, który kategorię geopoetyki wprowadził do refleksji literaturoznawczej dziesięć lat przed Kennethem White'em, miał niewątpliwie kontakt z żywo obecną we francuskim literaturoznawstwie przełomu lat 6o. i 70. ideą dotyczącą związków literatury z przestrzenią geograficzną. Tłumaczone przez Stachurę wiersze Michela Deguy oraz prowadzona przez poetów korespondencja miały inspirujący wpływ na poetykę autora książki Wszystko jest poezja, w której manifestuje przekroczenie literatury ku rzeczywistości, podobnie jak czyni to francuski poeta. Stachura przytacza jego słowa, tłumaczące tezę „wszystko jest poezją": „poeta to ten, który chce pokazać ogrodnikowi, że być ogrodnikiem to być poetą" "Ważny dla Stachury kontakt z Michelem Deguy, co potwierdzają wymieniane między nimi listy ${ }^{5}$ oraz wywiady, mógł zaowocować - jak sądzę - wpływem na wyobraźnię poetycką autora Całej jaskrawości.

Tamże, s. 254 .

3 Michel Deguy (ur. 1930) jest teoretykiem literatury, poetą, eseistą i emerytowanym profesorem literatury na Uniwersytecie Paryskim (Université de Paris VIII Vincennes - Saint-Denis), gdzie wykładał od 1969 do 1999 roku. Autor książek Fragments du cadastre (Gallimard, Paris 1960), Poèmes de la Presqu'île (Gallimard, Paris 1961), Actes (Gallimard, Paris 1966), Figuration (Gallimard, Paris 1969), Au jugé (Galilée, Paris 2004).

4 E. Stachura Wszystko jest poezja..., s. 69. Tytuł książki Stachury bliski jest głoszonej przez Michela Deguy idei "la poésie tout entière".

5 W książce Wszystko jest poezja Stachura wspomina o korespondencji z Michelem Deguy (s. 69) oraz o wizycie francuskiego poety w Warszawie („W przedwielkanocny Wielki Tydzień przyszybował z Paryża Michel Deguy. Dwa dni i jedną noc chodziliśmy po ulicach Warszawy, po czym Michel, jak był przyleciał, tak odleciał", s. 95). Marian Buchowski w książce Buty Ikara. Biografia Edwarda Stachury (Iskry, Warszawa 2014), na podstawie korespondencji, przedstawia towarzyskie i zawodowe kontakty między pisarzami (s. 198-192, 520-523). 
Ten, być może, jest pierwszym polskim poetą, który zetknął się z ideą geopoetyki u jej źródeł. Chciałabym spojrzeć na wspomnianą powieść właśnie z perspektywy geopoetyckiej, a nawet zaryzykować stwierdzenie, że jest ona (oprócz innych utworów Stachury) ciekawą formą artykułowania doświadczenia przestrzeni geograficznej, postrzeganej przez pryzmat jej potencjału poetyckiego. Interpretację tę warto poprzedzić krótkim przedstawieniem założeń twórcy geopoetyki pierwszej.

Michel Deguy swoją oryginalną koncepcję geopoetyki wyłożył w 1969 roku w książce Figurations. Odchodząc - wraz z poetami skupionymi wokół założonego przez siebie w 1968 pisma "L'Éphémère” - od immanentnej koncepcji dzieła literackiego, zwrócił się ku przestrzeni geograficznej rozumianej jako źródło wyobraźni poetyckiej. Proponując pisownię "géo-poéthique", podkreślał etyczny aspekt proponowanej dyscypliny, za której zadanie uznał nie tylko poetyckie, ale też odpowiedzialne zamieszkiwanie świata. Michel Collot - teoretyk zajmujący się związkami literatury i geografii - w swojej monografii Pour une géographie littéraire ${ }^{6}$ podkreśla prekursorski charakter geopoetyki Michela Deguy, który w swoich pracach - Fragments du cadastre oraz Poèmes de la Presquîle - inspirowanych doświadczeniem przestrzeni geograficznej, wprowadza metaforę mierniczego terytorium, najlepiej oddającą ideę bezpośredniego kontaktu człowieka z przestrzenią geograficzną. Mierniczy, podejmując się zadania wymierzenia i opisania Ziemi, przemierza ją własnymi stopami. Postrzega krajobraz jak spektakl, który wzbudza zachwyt formą organizacji przestrzeni, porównywalną do struktury zdania czy związków wyrazowych. „Wszelki logos jest topologią"7 - twierdzi zatem Deguy - pisząc o „składni tego, co postrzegalne”, odpowiadającej składni językowej. Wszystkie elementy krajobrazu widzi więc jako grę złożonych, sensotwórczych relacji, których konfigurację uznaje za pierwowzór figur poetyckich. Deguy - co podkreśla Collot - często cytuje zdanie Mallarmégo: ,żadna figura nie przewyższy figury doliny, łąki, drzewa"8. Przenoszenie znaczenia z jednej rzeczy na inną, metaforyzacja, rozgrywa się - jak zauważa Deguy - w polu widzenia, a więc ma charakter doświadczenia przestrzennego. Metaforę przestrzenną nazywa „metaforą pierwszą", gdyż w niej odbija się podstawowy związek człowieka z Ziemią.

6 M. Collot Pour une géographie littéraire, Éditions Corti, Paris 2014.

7 Tamże, s. 108-109.

8 Tamże, s. 109. 
Za ważną cezurę w twórczości autora Fragments du cadastre Collot uważa rok 1987, w którym poeta otworzył się na nowy wymiar twórczości wyrastającej z fascynacji przestrzenią miejską. W praktykowaniu geopoetyki przez

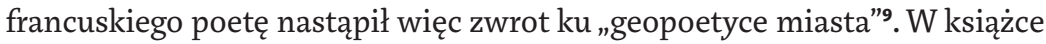
Au jugé, wydanej w 2004 roku, Deguy wraca do geopoetyki, rozumianej jako poszukiwanie związków między krajobrazem, myślą i wyobraźnią, przekonany, że przedstawiający się w polu naszego widzenia krajobraz użycza naszym myślom swoich figur.Źródłem takiej refleksji są często cytowane przez niego słowa Friedricha Hölderlina o artystach, których zadaniem jest „zbieranie piękna ziemi". W 2007 roku Deguy ponownie otwiera temat geopoetyki, a nawet proponuje pojęcie „geo-logiki poetyckiej” jako wyrażające stwierdzenie, że pewne widoki Ziemi (np. równik, rzeka, góry, same w sobie bezgraniczne i niewyczerpane) są nośnikami logosu, a powinnością poetów jest jego interpretowanie w ich własnym języku ${ }^{10}$. Według niego motyw geograficzny służy wyobrażeniu poetyckiemu, czyli topografia staje się tropologią?1. Przytoczony

9 Tamże, s. 111. Michel Deguy jest kontynuatorem praktyk przestrzennych flânerie Charles'a Baudelaire'a, autorem książki Spleen de Paris (Galilée, Paris 2001) oraz rozpoznawanym w Paryżu cyklistą, doświadczającym miejskiego krajobrazu w ruchu. Performatywne doświadczenie miejskiej przestrzeni było także udziałem Edwarda Stachury, którego Deguy zaprosił do udziału w wydarzeniach wzorowanych niewątpliwie na akcjach paryskich sytuacjonistów. W jednym z wywiadów Stachura wspomina nocne wyprawy na ulice Paryża, organizowane przez artystów skupionych wokół pisma „Po\&sie", założonego przez Michela Deguy. Wyprawy, podczas których malarze malowali obrazy na parkanach, a poeci pisali wiersze, odbywały się pod hasłem "la phalène" (ćma), gdyż, jak wyjaśnia Stachura, "kiedy się zastanawialiśmy, jak nazwać to, co mamy robić, wleciała ćma". Dalej pisarz opowiada o „falenach”: „Raz trafiliśmy na wesołe miasteczko i tam narobiliśmy dużo szumu, bo zaczęliśmy czytać na głos wiersze Apollinaire’a, odciągając ludzi od różnych huśtawek, gabinetów luster, itd. Albo na przykład, gdy trafiliśmy na rozbity samochód, rzeźbiarze wyciągali narzędzia i robiło się z tego samochodu jakieś tam, tak zwane dzieło". Zob. Edward Stachura o Michelu Deguy - YouTube (nagranie archiwalne niepublikowane), www.youtube.com/watch?v=5ztpbo4HXgo. W Całej jaskrawości jest scena, która być może niesie wspomnienie tych paryskich wypraw w towarzystwie Michela Deguy: "Ćma usiadła na główce kapusty. Miałem słabość do ciem od dwóch lat, od pamiętnej dla mnie jesieni tysiąc dziewięćset sześćdziesiątego czwartego. Brałem je delikatnie w ręce i wyrzucałem na dwór. Ale one uparcie wracały do światła, tłukły się od zewnętrznej w szybę. Dobijały się. Lubiłem coraz więcej te stworzenia. Patrzyłem na nie z jakąś czułością zmieszaną z żalem i litością. Chyba trochę dlatego, że to było tak, jakbym na siebie patrzył". Zob. E. Stachura Cała jaskrawość, Czytelnik, Warszawa 1969, s. 205.

M. Collot Pour une géographie littéraire, s. 112.

W latach 70. Algidras Julien Greimas tworzy koncepcję semiotyki topologicznej, odnoszącej się do opisu, wytwarzania i interpretacji przestrzennych typów mowy. Rozważa zatem „przestrzeń jako formę zdolną stanowić mowę przestrzenną pozwalającą mówić o rzeczach 
niżej fragment wiersza dobrze oddaje postawę poety „zbierającego piękno ziemi" czy przepisującego - przywołując słowa Stachury - wiersz z powietrza.

Poeta na progach z ekierką swojej sylwetki i jej cienia

Poeta Guliwer odrysowujący piórkiem Hopkonsa zimową kępę jeżyn

Lub pochylający się żeby za pomocą kompasu Gongory

Nastawić źdźbło trawy na zodiak. ${ }^{12}$

Z wyobraźni zdominowanej przestrzenią geograficzną wyłania się obraz kobiety w tańcu, wypełniającej sobą wszechświat i jednoczącą się z nim. Motywy geograficzne - widnokrąg, nieboskłon, las, perspektywa - stają się tropami. Według Michela Deguy proces metaforyzacji czy figuracji rozgrywa się właśnie w polu widzenia, a krajobraz użycza swoich figur wyobraźni twórcy. Twórczość rozumiana jest zatem jako artykulacja doświadczenia przestrzennego, podstawowego, gdyż dotyczącego związków człowieka z Ziemią.

Powietrze chwyta ją za kibić [...]

Jej sylwetka widnokręgiem nogi drogami ramiona nieboskłonem

jej sylwetka skrajem lasu ramiona perspektywą

Próżnia kontruje dla niej skrzydła

Kolorami są części jej odzienia przygotowane na krzesłach

jej uważny gorset

Świat jest jej tancerzem. ${ }^{13}$

Przywołane fragmenty utworów francuskiego poety, w przekładzie Stachury, pozwalają rozpoznać pokrewieństwo wyobraźni obu pisarzy, uprzestrzenniających doświadczenia egzystencjalne przez wykorzystanie metafor geograficznych. Obaj traktują bowiem przestrzeń geograficzną jako źródło tropów, a więc jako przestrzeń poetycką. Obaj wprawiają się w słuchaniu

innych niż przestrzeń". Tak więc figury świata, jak las, łąka, droga, dom, okno mogą przeistoczyć się w mowę przestrzenną, pozwalając mówić "przestrzennie" o rzeczach niemających wyraźnego związku z przestrzennością. Por. A.L. Greimas Ku semiotyce topologicznej, w: E. Leach, A.L. Greimas Rytuał i narracja, przeł. M. Buchowski, A. Grzegorczyk, E. Umińska-Plisenko, PWN, Warszawa 1989, s. 169-171.

12 M. Deguy [Poeta z profilu], przeł. E. Stachura, w: Wiersze, poematy, piosenki, przekłady, red. Z. Fedecki, Czytelnik, Warszawa 1984, t. 1, s. 428.

13 M. Deguy [Powietrze chwyta ją za kibić...], tamże, s. 422 
mowy krajobrazu, czytaniu tekstu krajobrazu, wyłanianiu z krajobrazu miejsc-metafor, które potwierdzają istnienie poetyki pierwszej, czyli „poetyki świata". Obaj więc niejako - przywołując raz jeszcze metaforę Stachury - „wyskakują z pociągu, żeby wejść w krajobraz, który ich nagle olśnił”. Jest to w istocie gest niezwykle geopoetycki, a można go odnaleźć zarówno w teorii geopoetyki autorstwa Deguy, jak też w tej zaproponowanej w 1979 przez White'a ${ }^{14}$, twierdzącego, że "geopoetyka zaczyna się wtedy, kiedy ciało wyrusza w przestrzeni"15. Wyobraźnia poetycka White’a, zdominowana otwartą przestrzenią, podąża wciąż za znikającym horyzontem. Przestrzeń jawi mu się jako wyzwanie do eksploracji, dla określenia której używa pojęcia ekstrawagancji, gdyż „extravagare” oznacza „błądzenie na zewnątrz”, ,błąkanie się poza". Za kluczową dla swojej wyobraźni przestrzennej uznaje figurę „poza” (dehors) ${ }^{16}$, a także pokrewne jej figury białego terytorium, marginesu, peryferii, litoralu, horyzontu, odnoszące się do idei przekraczania granic oraz otwartości na wszelkie obrzeża ${ }^{17}$.

Stachura pozostawił po sobie silnie zmetaforyzowany obraz poety w drodze ${ }^{18}$, błądzącego "poza” obszarem znanym w poszukiwaniu doświadczeń niezwykłych i osobliwych, czyli - jak powiedziałby White - ekstrawaganckich. Bohaterowie powieści Całajaskrawość, interpertowanej tu jako przykład artykulacji wyobraźni geopoetyckiej, wędrują, gubiąc się w „zakamarkach wszechświata” czy na „dzikich rubieżach czasu i przestrzeni”. Symbolicznego znaczenia, z racji swojej nazwy, nabiera wieś Zagubin, w której bohaterowie znajdują kwaterę w domu Potęgowej i skąd wyruszają na wyprawy po najbliższej okolicy. Wyprawy, których istotę najlepiej oddaje piosenka Wędrówka zyciejest człowieka a których opis niczym refren powraca w powieści:

I znowu szliśmy. A szliśmy cały czas, jakbyśmy przemierzali nie te trzy kilometry od rzeki do miasteczka, ale wielkie odległości, olbrzymie połacie

Swoją koncepcję geopoetyki Kenneth White wypracował w 1979 roku podczas podróży na Labrador, o czym pisze w książce Le Plateau de l'Albatros. Introduction à la géopoétique, Éditions Grasset, Paris 1994.

M. Collot Pour une géographie littéraire..., s. 113.

Zob. K. White La Figure du dehors, Le Mot et le reste, Paris 2014, s. 89-102.

Por. E. Konończuk W meandrach geopoetyki, „Teksty Drugie” 2015 nr 6.

Abstrahuję tu od towarzyszącej Stachurze legendzie podsycanej formułą "życiopisania”, zaproponowaną przez Henryka Berezę dla określenia jego pisarstwa. Dyskurs związany z tym faktem rekonstruuje Buchowski w Butach Ikara..., s. 203-216. 
przestrzeni i czasu. Setki tysięcy mil i całe stulecia. [...] Przechodząc nieraz z jednej strony ulicy na drugą albo idąc w lesie od jednego drzewa do drugiego, przemierzałaem odległość od horyzontu do horyzontu, od jednego krańca świata do drugiego. ${ }^{19}$

Doświadczenie „rubieży przestrzeni” wiąże się także z doświadczeniem "rubieży czasu”. White nazywa siebie poetą-kosmografem, wyrażając w ten sposób takie doświadczenie przestrzeni, w którym odsłania mu się „kosmologiczna poetyka wszechświata"20. W swojej poezji próbuje zapisać doznanie mające źródło w marzeniu, które budzi się podczas kontemplacji krajobrazu i pozwala podmiotowi zejść w głąb pamięci krajobrazu i dotrzeć do „archaicznego pejzażu". W poemacie White'a On Rannoch Moor ${ }^{21}$ pod wpływem wiejącego mroźnego wiatru cogito marzyciela jest nawiedzane przez wizję lodowca, który rozpoczął rzeźbienie terytorium w erze trzeciorzędu. Surowy, dziki, lecz fascynujący archaiczny pejzaż z aktywnym lodowcem wyłania się z pejzażu współczesnego, a właściwie jest odczytywany z tego pejzażu przez podmiot obdarzony wyobraźnią geologiczną. Bohater Stachury podobnie wsłuchuje się w mowę krajobrazu, oddając się marzeniu i kontemplacji, dociera do pierwotnego głosu Ziemi. Zanurzony w krajobrazie, doświadcza przestrzeni przedhistorycznej, a tym samym odwiecznych związków człowieka z kosmosem. Niezwykłe doświadczenie - które można nazwać geopoetyckim, a nawet kosmopoetyckim, pozwalającym bowiem uczestniczyć w "kosmologicznej poetyce wszechświata" - jest więc udziałem narratora Całej jaskrawości, który leżąc na tratwie kołysanej przez fale rzeki, przenosi się w krajobraz prehistoryczny:

I tak, osłonięci od słabego wiatru, leżeliśmy. Na wodzie. Jak ci w koszu na Tybrze. [...] Od niedalekich kartoflisk na starorzeczu snuł się magiczny swąd palonych łętów. Po wodzie rozgłośnie niosły się krzyki blaszkodziobych. Inne dochodziły nas słuchy. Dalsze. I jeszcze dalsze.

19 E. Stachura Cała jaskrawość, s. 54.

Zapisem podróży w poszukiwaniu "kosmologicznej poetyki przestrzeni” jest książka Kennetha White'a La carte de Guido. Un pèlerinage europeén, Albin Michel, Paris 2011. Zob. też K. White Poeta kosmograf, oprac. i przeł. K. Brakoniecki, Centrum Polsko-Francuskie Côtes d'Armor-Warmia i Mazury, Olsztyn 2010.

21 K. White On Rannoch Moor, w: tegoż Open World. The Collected Poems 1960-200o, Polygon, Edinburg 2003, s. 100. 
Starożytne. Ciężki oddech wojownika biegnącego z nowiną z Maratonu do Aten. Jeszcze dalsze. Prehistoryczne. Chrzęst żwiru pod sunącym czołem lodowca. I jeszcze dalsze. Szum ten przy narodzinach planety. Więc te dochodziły nas słuchy i te pobliskie: gulgot płynącego pod nami nurtu, brzegiem idące rozmowy, wiatr napowietrzny, jakby melancholijna zwrotka trznadla od łęgów rozlewiskowych, charkot motocykla na wale, dzwon zza rzeki. [...] Więc to słyszeliśmy i w ogóle. Wszystko. Całą nędzę i całą wielkość. ${ }^{22}$

Zbieżne obrazy poetyckie - które według Stachury dowodzą „udziału w wielkiej jedności" ${ }^{23}$, a według White'a „kosmosu we wnętrzu człowieka [...] jasności"24 - wskazują na podobny typ wyobraźni poetyckiej. Gaston Bachelard w Poetyce marzenia, w rozdziale Marzenie i kosmos opisuje doświadczenie kontemplacji pejzażu mające charakter kosmicznego marzenia, w efekcie którego powstaje doznanie jedności świata, jego jasnego widzenia oraz spokojnego, afirmatywnego zamieszkiwania.

Poprzez kosmiczność obrazu wzbogacamy się o doświadczenie świata, dzięki kosmicznemu marzeniu zamieszkujemy świat. Daje ono marzycielowi wrażenie bycia u siebie w wyobrażonym świecie. Wyobrażony świat powierza nam owo „u siebie” w stanie ekspansji jako odwrotność takiego „u siebie”, kiedy mówimy: „w swoim pokoju”. [...] marzenie jest świadomością dobro-bytu. Zarówno w kosmicznym obrazie, jak i w obrazie swojego domu jesteśmy w dobro-bycie wytchnienia. ${ }^{25}$

Cała jaskrawość wyraża kondycję człowieka będącego w drodze, a właściwie zamieszkującego świat poprzez bycie w drodze. Abstrahując tu od różnorodnych odczytań, utrzymanych czy to w nurcie refleksji psychologicznej, socjologicznej, czy też filozoficznej ${ }^{26}$, chciałabym zaproponować

\section{E. Stachura Cała jaskrawość, s. 48.}

Tamże, s. 56.

K. White Testament litoralu, w: tegoż Poeta kosmograf, s. 177.

G. Bachelard Poetyka marzenia, przeł. L. Brogowski, słowo/obraz terytoria, Gdańsk 1998, s. 203.

Cała jaskrawość odczytywana bywa przez krytyków jako zapis życia w PRL-owskim miasteczku, świadectwo przejawów kryzysu psychicznego autora, realizacja formuły życiopisania bądź artykulacja postawy egzystencjalnej. 
interpretację powieści Stachury jako ekspresji takiej wyobraźni przestrzennej, którą można nazwać geopoetycką. W Catej jaskrawości wyraża się kondycja człowieka rozumiana jako dążenie do nawiązania łączności z harmonią i rytmem świata, do jego zamieszkania nie przez zakorzenienie się w konkretnym miejscu, ale przez nieustające wędrowanie, będące w istocie poddawaniem się bezustannemu ruchowi, pulsowi wszechświata. Bohaterowie Stachury, zagubieni na drogach świata, zatrzymują się na chwilę w miejscach, w których się nie zadomowiają, przez które przechodzą niespiesznie, kontemplując je z namysłem i szacunkiem. Każda czynność, wykonywana przecież w natchnieniu, a więc w istocie będąca poezją, stanowi głębokie doświadczenie i w wymiarze estetycznym, i egzystencjalnym. Doświadczenie o takim właśnie charakterze niesie dorywcza praca przy oczyszczaniu basenu w uzdrowisku, kwatera w chałupie Potęgowej we wsi Zagubin, a także młócka i rąbanie drzewa. Niezwykłym wydarzeniem okazuje się wyprawa na niedzielną wycieczkę do pobliskiej miejscowości. Wycieczka ta mogłaby być interpretowana jako niezwykle ciekawy zapis życia w małym PRL-owskim miasteczku, ale interesuje mnie jako wyprawa podjęta w celu przemieszczania się „powłóczystym” krokiem po małomiasteczkowej przestrzeni. Narrator swoją opowieścią o niedzielnym spacerze wpisuje się w formułę opowieści przestrzennych Michela de Certeau, a więc opowieści artykułujących doświadczenie przestrzeni i jej praktykowanie. Ważnym tematem w teorii de Certeau są strategie spacerowania po mieście, rozumiane jako tworzenie w jego przestrzeni różnego typu tekstów, na których znaczenie składają się miejsca mijane w trakcie wędrówki. Spacer staje się zatem swoistym „pieszym aktem wypowiadania"27. Niedzielna wycieczka do pobliskiego miasteczka może być odczytana w konwencji metafory spaceru-tekstu właśnie jako piesza wypowiedź, której tematem jest swoiste doświadczanie przestrzeni, czyli jej kontemplacja. Spacer rozpoczynają bohaterowie od centralnego miejsca, rynku obsadzonego lipami, gdzie ogarnia ich poczucie przynależności do uniwersum, a tu stają niczym poeta z wiersza Deguy „z ekierką swojej sylwetki i jej cienia"28.

Stanęliśmy i zapaliliśmy. Era była kenozoiczna, epoka holocen, rok milenijny, sezon jesienny, miesiąc latawca, dzień bezbłędny, godzina

27 M. de Certeau Wynaleźć codzienność: sztuki działania, przeł. K. Thiel-Jańczuk, Wydawnictwo UJ, Kraków 2008, s. 99-100.

28 Por. przyp. 12. 
przedpołudniowa, a chwila była cicha, leniwa i spokojna. Chwila była na lody z nitką karmelu. ${ }^{29}$

Celem niedzielnej wędrówki jest włączenie się w kosmiczny rytm świata, aby doświadczać go w przeżyciu estetycznym, w przekonaniu o jego poetyckiej naturze. Pierre Sansot proponuje mówić o doświadczaniu „momentów poetyckich"30 w krajobrazie i właśnie one są kontemplowane przez bohaterów powieści. Stają się także przedmiotem opisu, który można nazwać fenomenologicznym, gdyż umożliwia on dotarcie do istoty zjawisk. Maurice Merleau-Ponty nazywa fenomenologię metodą "odsłaniania świata" ${ }^{\text {"1 }}$ i taki zamiar odsłaniania poezji świata przyświeca - jak sądzę - narratorowi Całej jaskrawości. Oto moment, w którym świat ujawnia swoją naoczną poetyckość, a słowa ją odsłaniają:

Od czasu do czasu z czarnoleśnych drzew rosnących wokół kościoła osypywał się liść. Wiatr drobny był. Lekki zachodni favonius. Straszliwie łagodny. Ale powietrze drżało od organowej muzyki i rozmodlonego niebywałego upału tej drugiej połowy października. Drżenie to właśnie, a nie zefir, strącało od czasu do czasu liście z pojedynczych drzew. ${ }^{32}$

W innym momencie spojrzenie wędrowców przyciąga rzeka, wywołując marzenie zanurzenia się w niej, zanurzenia się we wszechświecie, dając tym samym poczucie bezpieczeństwa i schronienia w otaczającej przestrzeni:

Jesiennie czysta, w różowej mgiełce, rzeka niosła swoje wody na północ. Gdzie kula globu spłaszczona. - Ech. Prześlizgnąć się po tym głową, aż

\section{E. Stachura Cała jaskrawość, s. 97.}

Kategorię "momentów poetyckich" zaproponował Pierre Sansot, który w książce Poétique de la ville [Poetyka miasta] bada fenomen Paryża metodą opisu fenomenologicznego. Ta metoda pokazuje bowiem, jak zjawiska przestrzenne jawią się w naocznym wyglądzie. "Momenty poetyckie" to szczególny typ relacji emocjonalnych, zachodzących między miastem a doświadczającym go człowiekiem, to miejsca (np. ulice, skwery, bulwary, mosty, skrzyżowania), które wprowadzają mieszkańca lub turystę w stan wzburzenia bądź zadowolenia, inspirują jego myśli czy pobudzają do działania. Por. P. Sansot Poétique de la ville, Petite Bibliothèque Payot, Paris 2009, s. 13. Pierre Sansot, wydając swoją książkę w 1971 roku i wpisując ją w kontekst „geografii emocjonalnej dzielnic", stał się właściwie prekursorem geopoetyki miasta. M. Merleau-Ponty Fenomenologia percepcji, przeł. M. Kowalska, J. Migasiński, Fundacja Aletheia, Warszawa 2001, s. 18.

E. Stachura Cała jaskrawość, s. 99. 
do końca - powiedział Witek. I już ślizgaliśmy się, już sunęliśmy, już lecieliśmy nad ledwo falującą taflą, nogi w górze, głowy w dół, ustami leciutko dotykając powierzchni wody. ${ }^{33}$

To marzenie o zanurzeniu, powracające wielokrotnie w powieści, jest w istocie marzeniem o połączenie bytu ludzkiego z Ziemią, w nadziei na udział w jej odradzającej się sile. W tym akcie zanurzenia jest także nadzieja na własne odrodzenie dzięki sile wszechświata, która pozwoli walczyć z nękającymi bohatera Catej jaskrawości atakami lęku i paniki, wprowadzającymi go w stan wewnętrznego rozpadu i wytrącającymi go z rytmu życia.

Stałem patrząc na wodę i słuchając szmeru. A potem klęknąłem, pochyliłem się i zanurzyłem w wodzie twarz. $Z$ otwartymi oczami patrzyłem na podwodne życie. Usta wynurzyłem nad wodę, tak że oddychałem spokojnie. Nurt przemykał mi po czole, po skroniach, po oczach zapatrzonych i tak jakby przez głowę przemykał mi nurt, przez mózgu wszystkie kanały [...]. Więc wszędzie dokładnie, w całej głowie, we wszystkich jej zakamarkach i chowankach słyszałem dzwonek pluskający bogini wód. Niewysłowiona była to jedna z tych chwil. ${ }^{34}$

Bohater „w natchnieniu nieustającym”, a więc w stanie, w którym zwyczajna czynność nabiera "niezwyczajnych barw, wagi, blasku i splendoru”, zanurza się w przestrzeń i w kosmicznym marzeniu doznaje jej odwiecznej jedności. To egzystencjalne doświadczenie, dające mu poczucie przylegania do świata, jego zamieszkiwania, uświadamia mu jednak, że „nie tak łatwo zostawić w wodzie odciśnięty ślad, nie tak łatwo zostawić w powietrzu odciśnięty ślad"35.

Wąwóz, do którego doszliśmy, wyżłobiony był w poprzek skarpy. Płytki i wąski tam, gdzie się zaczynał, schodził w dół do rzeki, rozszerzając się z biegiem płynącego na jego dnie strumienia. Na skrzydłach zbiegliśmy po zboczu nad brzeg trelującej po kamykach wody. Wyszukaliśmy nasłonecznione to miejsce, które czekało tu na nas od zamierzchłych czasów,

Tamże, s. 100. 
i usiedliśmy. I znowu: tak jak przedtem szliśmy po skarpie, jakbyśmy nic, tylko mieli iść tak wiecznie, tak samo teraz usiedliśmy. Identycznie. Jakbyśmy mieli usiąść tu na zawsze. Na wieczność. Tak usiedliśmy. W tym samym stylu. W tym samym duchu. Bo taki też między innymi był nasz do tego świata stosunek. ${ }^{36}$

Niedzielna wycieczka przynosi szczególne doświadczenie przestrzeni, pradoliny czekającej od zamierzchłych czasów na wędrowców, którzy idą przez nią, jakby mieli „iść tak wiecznie”, i którzy siadają w nasłonecznionym miejscu, jakby mieli „usiąść tu na zawsze”. Takie pozaczasowe doświadczenie przestrzeni White nazywa „źródłowym”, a takie doznanie egzystencjalno-estetyczne określa jako „białe” życiem chwilą", to zaś czytelnikowi Stachury przywodzi na myśl stan „całej jaskrawości”. Przywołane wyżej fragmenty powieści pokazują charakterystyczny dla pisarza typ wyobraźni przestrzennej, zdominowanej materialnością Ziemi, a więc wyobraźni geopoetyckiej, poprzez którą wyraża się potrzeba poetyckiego zamieszkiwania świata. Postawę bohatera Całej jaskrawości można wyrazić - jak sadzę - słowami White'a, który deklaruje w swojej twórczości zmierzanie do „estetyki życia”, uznając za Spinozą „pewną formę poznania, które jest największą radością istoty ludzkiej, i to poznanie-radość [...] zachodzi, kiedy pojedynczy podmiot czuje się zjednoczony z całym wszechświatem"38.

Przecięliśmy na ukos żwirownię, wspięliśmy się za nią na spadziste zbocze i staliśmy teraz na wysokiej skarpie, łapiąc szeroko oddechy. $\mathrm{Na}$ pewno nie wszystko, ale na pewno bardzo wiele różnych rzeczy, spraw i marnych idei uznałem, że mogę odstawić na bok, żeby popatrzeć półkolem na pradolinę. Co też uczyniłem. Popatrzyłem półkolem. Tak jakoś na równi z równym. I zobaczyłem całą jaskrawość. Zobaczyłem jaskrawie wszystko. Całość. Całą jaskrawość. [...] Zobaczyłem całą jaskrawość tego, że to nie chodzi, ni o śmierć, ni o życie, ni o sens i bezsens, ni o istotę $i$ istnienie, ni o przyczynę i skutek, ni o materię i ducha, ni o serce i rozum, ni o dobro i zło [...]. Chodzi o to wszystko razem wzięte i podane na tacy. ${ }^{39}$

Tamże, s. 116-117.

Por. K. White Poeta kosmograf, s. 47-48. 
Bohater-narrator Całejjaskrawości - podobnie jak autor, którego alter ego łatwo rozpoznać w narratorze - za cel życia przyjmuje wędrowanie poza utartymi szlakami, przemierzanie stopami Ziemi i zbieranie jej piękna. Z wyobraźni przestrzennej Stachury wyłaniają się obrazy poetyckie, które przynależą już nie tylko do geopoetyki, ale do White'owskiej "kosmologicznej poetyki wszechświata". Wyobraźnia zdominowana kosmicznym marzeniem warunkuje - jak powiedziałby Bachelard - jasne widzenie jedności świata oraz doświadczenie jego zamieszkiwania. Człowiek odczuwający ruch wszechświata, żyjący w jego rytmie, nie jest przywiązany do konkretnego miejsca na Ziemi, ale zawsze wędruje w jakieś obszary „poza”. Orientuje się w przestrzeni według gwiazd. Ten motyw często występuje w powieści Stachury, a obrazy nieba i gwiazd służą wyrażeniu głębokiej więzi człowieka ze wszechświatem, jego udziału w „wielkiej jedności”.

Paliliśmy papierosa w starannym milczeniu. Nie trzeba było podnosić głowy, żeby zobaczyć po zachodniej, nisko na niebie, pierwszą gwiazdę, z którą to czy ja bym nie zatańczył? Wyżej inne gwiazdy coraz to pojawiały się nowe, otaczając nas jak fladry, jak czerwone te chorągiewki, którymi znakuje się ostęp z otropionym zwierzem w celu jego umiejscowienia. Spokojnie, spokojnie. Jesteśmy tu, na ziemi, i nikt się z tym nie kryje. Ognika papierosów w zwiniętej tubce dłoni nie chowamy. My też gwiazdy. Chude gwiazdy. Nie pierwszej wielkości jak Rigel, Betelgeuze, Deneb, Antares, Kłos, Capella czy Aldebaran. Ale jednak. My też gwiazdy, mówię. I mówię to do gwiazd. Do nich się zwracam wprost..$^{40}$

[...] mleczną drogę, którą każdy w sobie ma, każdy w sobie nosi te miliardy gwiazd, gasnących powoli jedna po drugiej, zjadanych przez troski, choroby, nieszczęścia i kataklizmy, ale dużo ich - gwiazd, niezliczenie, miliardy i jeszcze ciągle nowe się rodzą i może to jest to, co trzyma nas. Może to jest to, ten ciężki cud, za sprawą którego udaje się jednak wyleźć z mroków jamy na powierzchnię, i żyje się dalej. Świeci się dalej.41

Obraz bohatera z ognikiem papierosa w dłoni (powracający motyw w powieści Stachury), stanowi jakoby ilustrację słów Bachelarda, że „najprostsze

\footnotetext{
40 Tamże, s. 33.

41 Tamże, s. 38-39.
} 
palenisko stanowi ramy wszechświata"42. Człowiek obserwujący gwiazdy, przywołujący je imieniem, mierzący palcem odległości między nimi sprawia wrażenie „stopionego" ${ }^{13}$ ze wszechświatem, zawładniętego marzeniem kosmicznym, w którym kontemplowany świat widziany jest w pełnej jasności jako wielki i piękny.

W tym wielkim i pięknym porządku wszechświata poczesne miejsce zajmuje mała wieś Zagubin, a w niej waląca się stodoła biednej Potęgowej. Bohater, często obserwujący niebo przez sito dachu starej stodoły, postrzega ją jako element scenerii krajobrazu, trwający w nim dzięki aktywnej obecności gwiazd.

Niebo, ech, cudne manowce, niebo skrzyło się niezliczenie jak ikra trących się w rzekach jesiotrów. Nad przechyloną stodołą widać było wyraźnie podtrzymującą ją konstrukcję gwiazd. Dokładnie konstelacja Wieloryba podtrzymywała stodołę. A ściśle z Wieloryba gwiazda omikron zwana Mirą albo Cudowną. ${ }^{44}$

Bohaterowie przed opuszczeniem Zagubina, w tajemnicy przed Potęgową, chcą wykorzystać wichurę, aby zaaranżować zawalenie się stodoły, która podparta drągami nadawała się do rozbiórki. Powalona przez wiatr, mogłaby przynieść Potęgowej korzyści w postaci ubezpieczenia. W oczekiwaniu na wiatr mijają tygodnie, a bohaterowie opracowują plan współpracy z nim.

Zaczynał dmuchać wiatr z północo-zachodu. Pierwszy to był raz, że udało mi się zauważyć, że udało mi się przyłapać ten słynny moment początku wiatru. Trochę wzruszony byłem, przyznaję. Dla obserwatora przyrody, za jakiego się miałem, to była gratka nie lada przyłapać wiatr w jego zaraniu, w jego samym początku. Przyłapać ten słynny moment, kiedy wiatr wyłania się, wstaje na nogi i zaczyna biec na przełaj. ${ }^{45}$

Fascynacja wiatrem przejawia się w licznych jego opisach, tych astronomicznych uwzględniających „, siłę Coriolisa, czyli siłę wywołaną wirowaniem

G. Bachelard Poetyka marzenia, s. 221.

Jest to pojęcie ze słownika Bachelarda. Por. tamże, s. 226. 
globu wokół własnej osi”, jak i tych doceniających jego poetycki wymiar. Głos narratora, dochodzący ze „średnich szerokości, gdzieś na 53-cim stopniu szerokości północnej, ze wsi Zagubin"46, odsłania poetykę wiatru, który czyni z lasu kościół z buczącymi na chórze organami, który hulając po dolinie, porywa do tańca wszystko, co stoi mu na drodze, który siano wyszarpane ze stogów formuje na polu na kształt morskiej fali, który w końcu kuksańcami zmusza człowieka do szybszego kroku i ugięcia karku w pokorze. Przewijające się przez Cała jaskrawość obrazy zdominowane żywiołem powietrza, ciekawie korespondują z fragmentem prozy poetyckiej Michela Deguy, wskazując na pokrewieństwo charakteru wyobraźni poetyckiej obu twórców ${ }^{47}$.

Więc wiatr zawiał w piątek. Tego dnia on wyskoczył na arenę i powiał po widowni zrazu lekko, nieśmiało, potem mocniej, a po południu rozpędził się straszliwie. [...] Niech posłucha, kto ma serce, jak gwiżdże wiatr. ${ }^{48}$

I oto właśnie doczekaliśmy się go i godzina obalenia stodoły zbliżała się wielkimi krokami, bo wiatr był taki, jakiego potrzebowaliśmy. Dziki, bandycki wiatr hulał po dziedzinie i jeszcze się rozpędzał, i nic już chyba dzisiejszej nocnej wichurze nie mogło stanąć na przeszkodzie. ${ }^{49}$

Wiatr pojawia się w Zagubinie, gdzie na osłoniętej nocą scenie świata ma nastąpić dramat upadku stodoły. Popychani przez wiatr bohaterowie, zaopatrzeni w drągi i szpadel, zamierzają pomóc wichurze w dziele zniszczenia. Wprzęgając siebie w działanie żywiołu, stają się jego pomocnikami i zarazem uczestnikami kosmicznego spektaklu. Można zatem powiedzieć, parafrazując słowa Michela Deguy, że bohater, alter ego Stachury, poeta, „nie stawia pułapek na wiatr, ale ustala rytm jego biegu, wskazuje mu przejścia tajne i przełęcze"50.

Tamże, s. 224 .

„Wielki feudalny wiatr przebiega ziemię / W czystej pogoni pochyla łany zbóż, ociosuje rzeki, listek po listku wybiera spod strzech [...] zaś plemię ludzi stawia nań pułapki z osiki, wznosi palisady z cyprysów, [...] wyniosłe wiatraki przeciw-mu-stawia. / Poeta jest zdrajcą zaopatrującym wiatr w racje, w prowiant, ustala rytm jego biegu, ponagla swoimi lirami, wskazuje przejścia tajne i przełęcze". M. Deguy [Wielki feudalny wiatr przebiega ziemię], przeł. E. Stachura, w: Wiersze, poematy, piosenki, przekłady, s. 394.

E. Stachura Cała jaskrawość, s. 209.

Tamże, s. 227.

Zob. przyp. 47. 
Cała jaskrawość odczytuję jako artykulację takiego doświadczenia przestrzeni, jakiemu pisarz daje wyraz w książce Wszystko jest poezja. Rozwijając piękną metaforę otwierającą tę opowieść-rzekę, można powiedzieć, że bohater-narrator wchodzi w krajobraz, który go olśnił, wtapia się weń, idzie na sagę przez pola i wie, że jest to przepiękny wiersz, tyle że nie zapisany na papierze, ale jest poetą i umie ten wiersz przepisać z powietrza. Bohaterowie Stachury doświadczają piękna wpisanego w miejsce i tym samym realizują ideę Hölderlina głosząca, że to właśnie rolą artystów jest zbieranie piękna Ziemi. Stachura, jako tłumacz i przyjaciel Michela Deguy, twórcy geopoetyki, niewątpliwie był obdarzony wrażliwością podobną do wrażliwości francuskiego kolegi po piórze. Podobny charakter wyobraźni poetyckiej obu twórców, zdominowanej refleksją nad przestrzenią w jej geograficznym wymiarze, sytuuje Edwarda Stachurę w bliskim kontekście geopoetyki.

\section{Abstract}

\section{Elżbieta Konończuk}

UNIVERSITY OF BIAŁYSTOK

Edward Stachura: A Geopoet

Konończuk examines the work of poet and writer Edward Stachura through the prism of geopoetics. As a translator and friend of the French poet and literary theorist Michel Deguy, who proposed the concept of geopoetics ten years before Kenneth White, Stachura was aware of the idea - popular with French literary scholars in the late 1960s and early 70s - that literature and geographical space were interlinked. To explore the spacial nature of Stachura's imagination Konończuk discusses his novel Cała jaskrawość [All the Brightness] in which the author articulates his experience of geographical space as an enormous poetic potential. Konończuk reads the novel as an elaboration on the metaphor that opens Stachura's collection of impressionistic essays Wszystko jest poezja [Everything is Poetry], whose protagonist-narrator enters the landscape aware that it is an unwritten poem; as a poet he is able to transcribe it out of the air.

\section{Keywords}

Edward Stachura, Michel Deguy, geopoetics, space, Cała jaskrawość [All the Brightness] 